\title{
Rural Households' Allocation of Remittance Income in Agriculture in Nepal
}

\author{
Prem B. Bhandari ${ }^{a, *}$ \\ ${ }^{a}$ Population Studies Center, Institute for Social Research, University of Michigan, Ann Arbor, MI 48106, USA
}

\begin{tabular}{l} 
M A N U S C R I P \\
\hline Article history: \\
Received 23 Jan 2019 \\
Received in revised fo \\
Accepted 25 Oct 2019 \\
\hline Keywords: \\
household activities \\
farming \\
Nepal \\
remittance use
\end{tabular}

\section{Citation:}

Bhandari, P. B. (2019). Rural households' allocation of remittance income in agriculture in Nepal. Global Journal of Agricultural and Allied Sciences, $1(1), 1-10$.

\section{Introduction}

This study investigates household's allocation of remittance income in farming and other household activities by remittance-receiving households and examines the extent to which the amount of remittances used in farming and other household activities varies by total amount of remittances received by a household. The study used the detailed household level data collected in 2014 from a rural migrant-sending setting of south-central Nepal.

Nepal is experiencing massive out-migration of youths. The country has thus become increasingly dependent on remittances. More recently, individuals have been more mobile than any time in the history. Outmigration of youths from poor agrarian societies to rich and developed societies has been a worldwide phenomenon. In 2015, 3.3 percent of the world's populations were international migrants. This number increased from an estimated 214 million people in 2010 to 244 million in 2015 (IOM, 2017; World Migration Report, 2010, 2015). The flow of remittances in migrant-sending countries is also increasing with the growth of the number

\footnotetext{
* Corresponding author. E-mail address: prembh@umich.edu
} 
activities. More specifically, this paper investigates the allocation of remittances received by households in farming and in other dimensions of household activities in the Chitwan Valley of Nepal. I hypothesize that the amount of remittances received by a migrant-sending household is positively associated with its use in farming. In Nepal, the investment in farming is constrained by the availability of finances or credit. This constraint will be removed by remittances received from migrants. Additionally, this paper investigates the household-level factors associated with the amount of use of remittances in farming as well as in various other household activities.

This understanding is important because the consequences of outmigration for sending societies have been a major concern from a policy perspective. One such consequence is the effect of remittances on the migrant-sending societies. Previous studies were not able to examine such consequences partly due to the lack of appropriate data. This study will help understand the uses of remittances in various household activities empirically using the uniquely detailed data from a remittance dependent setting of rural Nepal with tremendous potential for agricultural improvement.

\section{Uses of Remittances: A Review}

Scholars and policymakers around the globe are increasingly interested in studying the uses of remittances by remittance-receiving households in developing countries. The proponents of the New Economics of Labor Migration (NELM) theory argue that migrants are an key source of household income. This earned income from remittances is invested in productive activities such as in farming (Kindleberger, 1967; Taylor \& Yúnes-Naude, 1999). For example, Adams (1998) found that in rural Pakistan remittances significantly contributed to the purchase of land. According to Adams, this to the tendency of households to use remittances on land purchases is due to a higher rate of return than other assets such as vehicles and bikes. Ecer and Tompkins (2013) and Oberai and Singh (1980) also reported that remittances were used as productive investments such as the buying of farm land, equipment, and farm inputs such as seeds and fertilizers. Those who hold pessimistic view on migration and remittances argue that a large amount of remittances received by households in developing countries are used for consumption such as food, houses construction and on other purposes such as feasts, funerals, weddings, and medical bills (Ecer \& Tompkins, 2013; Koc \& Onan, 2006; Oberai \& Singh, 1980; Rempel \& Lobdell, 2007; Taylor, 1999).

Researchers also argue that the households use remittances for both in consumption and production (De Haas, 2007; Eversole \& Johnson, 2014; Stark \& Bloom, 1985; Taylor \& Martin, 2001). In a study in the Philippines, Eversole and Johnson (2014) found that the households used remittances for consumption, production, health and education. Bhandari and Chaudhary (2017) also reported that the remittances were used by households in productive as well as consumptive purposes in Nepal.

\section{Migration and Remittances in Nepal}

Both internal and international migration are common in Nepal and the country has a long experience of both. During 1950s, Nepal experienced internal migration when the Terai region (Southern plain) was opened for settlement. Since then migration to the Terai region, especially from the Hills and Mountains, has rapidly increased (Gurung, 1998; Shrestha, 1990).
International migration, particularly the labor migration of Nepali youths to international destinations began during the first half of the 19th century. This out-migration of youths started with the recruitment in The British Brigade of Gurkha (Gurung, 1983; Rathaur, 2001; Thieme \& Wyss, 2005). Since then, in 1985, the Government of Nepal enacted the Foreign Employment Act. Following this Act, the manpower companies were formally allowed to send Nepalese workers abroad. This is the beginning of the expansion of migration streams outside of India (Kollmair, Manandhar, Subedi \& Thieme, 2006; Thieme \& Wyss, 2005).

Reports show that there are about three million Nepalese working abroad (World Bank, 2009; Government of Nepal, 2071 (2014)). The 2011 population census reported about two million individuals as migrants (Central Bureau of Statistics, 2012). More recent anecdotal estimates show between 4-6 million people outside of Nepal. Undocumented emigrants outside of the country, which is also very high, is difficult to estimate precisely. At present, migration has been a 'rite of passage' and a matter of social status and prestige (Thieme \& Wyss, 2005). Over 1500 Nepali youths have been estimated to move outside of the country daily (Kern \& MüllerBöker, 2015; Pattison, 2014).

The volume of remittances received by households is also increasing over time. In 2014, Nepal received US\$6.6 billion of remittances from migrants, which accounted for approximately 29 percent of country's GDP (World Bank, 2016). This amount excludes the remittances received through informal channels. As of 2014, Nepal was the third largest remittance-receiving country in terms of its contribution to GDP in the world (World Bank, 2011, 2016) and is among the largest remittance recipient countries in the South Asia region.

Rural households in Nepal receive remittances from both internal and international migrants (Hoermann \& Kollmair, 2009; Pant, 2008; Seddon et al., 2002; Sharma \& Gurung, 2009). According to the Nepal Living Standard Survey (2010/11), 56 percent of the households received remittances (Central Bureau of Statistics, 2012). Estimates show that a household received NRs. 80,436 (in nominal terms) in the form of remittances (Nepal Living Standard Survey, 2010/2011). This estimate comes to be NRs 9,245 in terms of per capita nominal remittances when the entire population is considered. In 2014/2015, the fifth Household Budget Survey (2014/2015) estimated that on average a household's share of remittances in its monthly income was NRs 5,304 (17.6\% of the total average monthly household income of NRs 30,121) (Nepal Rastra Bank, 2016). According to this survey, remittance was the third (17.6\%) most important source of a household's monthly income (NRs 30,121). The first two sources were salary, wages, allowance and pension (30.3\%) and business income (24.4\%). Remittance was reported to be the second most important source of household income in rural Nepal.

In a study recently conducted in the western Chitwan Valley, 75 percent of the households reported that they received remittances from migrants in the past 12 months (Bhandari \& Chaudhary, 2017). A household on an average received NRs. 150,562 (US\$1,505) as remittance in a year (NRs. 12,546 or US $\$ 125$ per month) (Bhandari \& Chaudhary, 2017). One-half of the migrant households received NRs 100,000 (median) per year (or NRs 8,333 per month). Among them, a household on average received 200,388 NRs (US\$2,004) of remittance in a year (NRs 16,700 or US\$167 per month). One-half of the remittance-receiving households received NRs 140,000 per year (or NRs 11,667 per month). 


\section{Empirical Evidence of Households' Uses of Remittances in Rural Nepal}

\subsection{The Study Setting}

I used the data from a pilot study conducted in 2014 (see for details Bhandari \& Chaudhary, 2017) in the western Chitwan Valley. In 1956, the Government of Nepal, in collaboration with the International Cooperation Assistance of the United States government initiated a malaria eradication program and distributed land to people. Consequently, Chitwan became a melting pot, receiving people from all over the country. Currently, the valley is inhabited mostly by in-migrants, especially from pahad, i.e., the Hill and Mountains and other nearby Terai districts and India.

Chitwan has been a hub for business and tourism due to its central location, well-developed transportation, communication, education, and health services. Moreover, Chitwan's proximity to the capital city of Kathmandu has made it accessible for people. This has led to a rapid increase of services, businesses, and employment opportunities in the district (Shivakoti, Axinn, Bhandari \& Chhetri, 1999).

This setting is important for this study because a large majority of households have farming as the key source of livelihood. In 2006, 84 percent of households in the Chitwan Valley Family Study (CVFS) area were involved in farming or animal husbandry. Mixed-farming is commonly practice by farmers. Crop-livestock are well integrated into the production systems. Land is primarily used for producing food grains. Livestock are raised for animal protein (milk, meat and eggs), draft power, and manure. Labor needed to perform various farm and non-farm activities commonly comes from within the family. More recently, the family mode of agricultural production is rapidly shifting throughout Nepal (Bhandari \& Ghimire, 2013; Pariyar, Shrestha \& Dhakal, 2001). Traditional laborintensive farming practices are gradually being replaced by modern farm inputs and equipment such as tractors, updated farm implements, and biochemicals.

Chitwan is one of the major migrant-sending districts in the country. According to 2011 census, 29 percent (27\% for Nepal) of the surveyed households in Chitwan reported that at least one member was absent from household. About 9 percent $(\mathrm{Nepal}=7 \%)$ of population migrated outside of Chitwan of which $16 \%(\mathrm{Nepal}=13 \%)$ were males and 2 percent $($ Nepal $=2 \%$ ) were females. Many youths are migrating outside of Nepal every year (see Bhandari \& Ghimire, 2013) and sending a large amount of remittances back home (Bhandari, 2016). These migrant-sending households utilize remittances in a variety of tasks (Bhandari \& Chaudhary, 2017).

\subsection{Data}

The data for this study was collected in 2014, which reflected the information for 2013. The migrant-sending households were identified from 30 randomly selected neighborhoods (see Barber, Shivakoti, Axinn \& Gajurel, 1997 for details). For the purpose, the study area of the western Chitwan Valley was first divided into three strata based on the approximate distance from Narayanghat (about one-third of a total distance of nearly 30 $\mathrm{km}$ from Narayanghat to Laukhari), to select a representative sample of neighborhoods. Stratum 1 included areas nearest to Narayanghat, stratum 3 included areas farthest from it and stratum 2 included areas in between. The samples were selected at two stages. Ten settlements from each stratum (a total of 30 settlements) were randomly selected based on probability proportionate to size, in the first stage. The settlements were then divided into several non-overlapping clusters called neighborhood or tol, each tol consisting of 5-15 households.

Ten neighborhoods or tols from each stratum were selected with a total of 30 communities from three strata. There were 394 households in 30 neighborhoods. Nearly half of the households $(47 \%)$ had at least one member (age 12 years and above) away from home (outside of Chitwan) for most of the time in the past six months. This estimate is consistent with the data from the Nepal Living Standard Survey (2010/11), which reported about 53 percent of households with at least one absentee member currently within or outside the country.

Data were collected from 185 eligible households using a face-to-face survey with a response rate of 99 percent. However, the information from 139 households that received remittances during the study period was used in the analysis. Data were primarily collected from the household head and in a few households, individuals 18 years and over who could provide information about the household, remittances and remittance use were interviewed. Standard practices of ethical codes for interviewing and data collection were followed. Consent was read to the informants and permission was obtained prior to the interview. Because this is a household level information, multiple informants were allowed to respond to survey questions. Overall, this study collected information about each migrant's demographic characteristics such as age, gender, current place of residence, marital status, and education. Here, migration is defined as any departure from the household/neighborhood and outside of Chitwan lasting at least three months or more in the past six months for work reasons. It included the migration of household members within or outside of Nepal.

A migrant's residential destination (such as a district or a country) in each month (for the last 12 months), migrant's occupation, a household's receipt of remittances (money, goods or gifts) from the migrant, and the amount of remittances received each household was collected. The information was recorded in a calendar (see Bhandari \& Chaudhary, 2017). In addition, the survey also collected data on whether a household spent any money on a specific domain/item of household activity. If a household spent money in any activity, it was confirmed whether the money came from the remittances or not and the amount of money invested/spent in each activity for each month. An approximate amount of remittances received by a household or used in each activity was collected. The respondents did not express any problem in reporting the value in rounding figures as the length of time was only for a year. For details, please refer to Bhandari and Chaudhary (2017).

\subsection{Measures}

Uses of remittance income (in Nepali Rupees) in the following domains of activities by remittance-receiving households in the past 12 months were examined in this paper. For analysis, the amount was logged to normalize the data.

1. Farming. This is the total amount of remittances (in Nepali Rupees) spent in buying items related to farming by a remittance-receiving household in the past 12 months. This includes the sum of remittances used to purchase seeds, pesticides, renting a tractor, hiring a wage laborer, feed or fodder for farm animals and poultry, use in fish farming, swine/pig farming, and buying of land for farming or animal husbandry. These items were measured separately and summed together for analysis.

2. Business, saving, and investment. This includes the total amount of remittances used in business, saving, and investment as reported by remittance-receiving households in the past 12 months. 
3. Human capital development. This includes the amount of remittances used by households, separately in health and education of household members.

4. Fixed assets such as ornaments, land, and property. This is the total amount of remittances used to buy property such as land, a new house, repair and maintenance of old house, and purchase of jewelry/ornaments (gold/silver) by a household in the past 12 months.

5. Household items. This is the total amount of remittances used to purchase various household items such as a bicycle, a motorcycle, a tractor, a pumpset, a car, a gobar gas plant, a gas stove, a rice cooker, a fridge, a fan, furniture and other items purchased during the survey period.

6. Media (electronic) items. This is the total amount of remittances used to buy various electronic media items such as a radio/tape player, a cell phone/telephone, a TV/VCR and a computer.

7. Food consumption. This is the total amount of remittances reported by remittance-receiving households to purchase food items. These items include cereal grains, pulses, vegetables, meat, milk products, oil/spices, and condiments (sugar, tea, coffee, horlicks).

8. Clothing. This is the total amount of remittances used to purchase clothing.

9. Cultural expenses. This includes the total amount of remittances spent in festivals and other cultural events like death rituals (arghau/funerals/shraddha) ${ }^{*}$, birth rituals (bratabandha/birthdays), rice feeding ceremony (annaprasan), pilgrimage, and worshiping (puja).

10. Utilities and other expenses. The total amount of remittances spent to pay water bill, electricity bill, telephone bill, mobile phone charges, buying mobile phone recharge cards, internet charges, donation (daan and chanda), house rent, and to buy cigarette or tobacco.

11. Debt payment. Total amount of remittances used to pay debt.

\subsection{Explanatory Measures}

The total amount of remittances received by a household was the major explanatory measure used to examine its influence on a household's use of remittances in agriculture. The information was collected by asking, "Altogether, how much money did you or your household receive in the past 12 months, including the value of any goods or gifts? Please also tell me when you received?" The amount reported by a household (in Nepali Rupees) for each migrant. The amount was summed for the year. Thus, the summed-up amount was then divided by the number of months the migrant was away from home to estimate a migrant's average monthly remittance. If a household consisted of multiple migrants, the remittance amounts incurred by all migrants from the same household were added to calculate the total remittance per household. The amount of average monthly remittance (natural $\log$ ) was used in the multivariate analysis.

I also used several control measures that included the total number of individuals in the household, gender of the household head (male/female), median age, median education (number of years of education), the major source of livelihood of a household (farming only, farming-business-

\footnotetext{
*Arghau - death ritual among Gurung community; Shraddha - worshipping and
} paying homage to ancestors among Hindu; Bratabandha - a ritual that a boy must go migration; or farming-migration), and caste/ethnicity (Brahmin/Chhetri, Dalit, Hill Janajati, Newar, and Terai Janajati) to adjust for their influence on the outcome measure. A household's annual income and its location or distance from the largest urban center of Narayanghat measured as near, far, and in between were also adjusted.

\subsection{Analysis}

First, I present the descriptive statistics of measures used. Second, because the data were multilevel in nature (migrant households clustered in neighborhoods), multivariate models using multilevel modeling (hierarchical linear modeling) techniques were estimated for each category of outcome measure. Because each of the outcome variables was measured as the total amount of remittances (in Nepali Rupees log-transformed) spent in various household activities including farming, a multilevel Ordinary Least Squares (OLS) regression as a multivariate tool was used to estimate the models. This strategy accounts for clustering of households within neighborhoods.

\section{Findings}

\subsection{Uses of Remittances in Farming and Other Household Activities}

Table 1 shows the summary statistics of measures used in the analysis. On average, a migrant household received a total of NRs 200,288 (a minimum of NRs 4,000 to a maximum of NRs 964,000) in a year.

The result shows that only 3.1 percent of total remittance (NRs 10,218) was spent by a household in farming. The largest amount $(27 \%)$ of remittances (NRs 89,136) was used by a household in buying fixed assets such as land, property and jewelry in a year (Figure 1). The second largest proportion $(15.3 \%)$ of remittances was used in food items, including cereals, non-cereals, dairy, and vegetables (NRs 50,219), followed by business and savings (NRs 40,388; 12.3\%) and education (NRs 36,775; $11.2 \%$ ). Of the total amount of remittances spent, 11 percent (NRs 36,179) was used on debt payment and 7 percent (NRs 23,191) was used in marriage, funeral, and birthday celebrations. A household used only 4 percent (NRs 13,513) of the total remittance in healthcare of the family members. The detailed list of household activities where a household used remittances is provided in (Bhandari \& Chaudhary, 2017).

\subsection{Multivariate Regression Results}

Remittance Use in Farming. The results (Table 2) show that the amount of remittances received by households was not significantly associated with the amount of remittances used in farming (-0.04; $p>.05)$. Interestingly, although statistically not significant, the total amount of remittances received by a household was negatively associated with its use in farming. The result suggests that despite the outmigration of a large number of youths from rural farming communities, remittance income has not been channeled for the improvement of agriculture at least in this setting of Nepal.

through before his marriage; Annaprasan - ceremony to initiate rice feeding in young children 
Table 1. Descriptive statistics of measures used in the analysis ( $n=139$ households).

\begin{tabular}{|c|c|c|c|}
\hline Measures & Description & Mean (Std. Dev.) & Min-max \\
\hline Outcome Measures & Nepali Rupees (NRs) & & \\
\hline Farming & NRs & $10,218(24,207)$ & $0-201,500$ \\
\hline Business, savings and investment & NRs & $40,388(164,833)$ & $0-1,695,000$ \\
\hline Human capital - Health & NRs & $13,513(33,923)$ & $0-300,000$ \\
\hline Human capital - Education & NRs & $36,775(63,695)$ & $0-360,500$ \\
\hline Fixed assets (land, house, jewelry) & NRs & $89,136(321,409)$ & $0-2,550,000$ \\
\hline Household assets & NRs & $5,384(19,429)$ & $0-165,000$ \\
\hline Electronic media items & NRs & $4,215(13,756)$ & $0-75,000$ \\
\hline Food, dairy and vegetables & NRs & $50,219(61,347)$ & $0-272,400$ \\
\hline Clothing & NRs & $6,293(15,708)$ & $0-150,000$ \\
\hline Debt payment & NRs & $36,179(89,379)$ & $0-700,000$ \\
\hline Festivals and cultural events & NRs & $23,191(59,219)$ & $0-412,000$ \\
\hline Utilities (house rent, utilities) & NRs & $12,561(43312)$ & $0-484,800$ \\
\hline \multicolumn{4}{|l|}{ Explanatory Measure } \\
\hline Total remittances received & NRs & $200,388.27(181,511.12)$ & $4,000-964,000$ \\
\hline \multicolumn{4}{|l|}{ Controls } \\
\hline Household members & Number & $5.40(1.87)$ & $2-13$ \\
\hline Mean age of individuals in the household & Year & $26.51(8.42)$ & $9-57$ \\
\hline Mean age of elderly people in the household & Year & $51.96(16.94)$ & $24-100$ \\
\hline Mean education of household members & Number of years & $6.85(3.05)$ & $0-12.5$ \\
\hline Livelihood option: Business and migration & 1 if yes, 0 otherwise & $0.27(0.45)$ & $0-1$ \\
\hline Farming, business and migration & 1 if yes, 0 otherwise & $0.19(0.39)$ & $0-1$ \\
\hline Farming and migration & 1 if yes, 0 otherwise & $0.52(0.50)$ & $0-1$ \\
\hline Total cultivated land & Kattha & $10.32(10.57)$ & $0-50$ \\
\hline \multicolumn{4}{|l|}{ Household income (Nepali Rupees) } \\
\hline Below 100,000 & 1 if yes, 0 otherwise & $0.35(0.48)$ & $0-1$ \\
\hline $100,001-250,000$ & 1 if yes, 0 otherwise & $0.19(0.39)$ & $0-1$ \\
\hline $250,001-500,000$ & 1 if yes, 0 otherwise & $0.18(0.38)$ & $0-1$ \\
\hline 500,001 and over & 1 if yes, 0 otherwise & $0.17(0.38)$ & $0-1$ \\
\hline \multicolumn{4}{|l|}{ Caste/ethnicity } \\
\hline Brahmin/Chhetri & 1 if yes, 0 otherwise & $0.44(0.50)$ & $0-1$ \\
\hline Dalit & 1 if yes, 0 otherwise & $0.17(0.38)$ & $0-1$ \\
\hline Hill Janajati & 1 if yes, 0 otherwise & $0.16(0.37)$ & $0-1$ \\
\hline Newar & 1 if yes, 0 otherwise & $0.10(0.30)$ & $0-1$ \\
\hline Terai Janajati & 1 if yes, 0 otherwise & $0.13(0.34)$ & $0-1$ \\
\hline \multicolumn{4}{|l|}{ Location of households from Narayanghat } \\
\hline Strata 1 (close) & 1 if yes, 0 otherwise & $0.34(0.47)$ & $0-1$ \\
\hline Strata 2 (middle) & 1 if yes, 0 otherwise & $0.34(0.47)$ & $0-1$ \\
\hline Strata 3 (far) & 1 if yes, 0 otherwise & $0.30(0.46)$ & $0-1$ \\
\hline
\end{tabular}

US\$ $1=100$ Nepali Rupees (2013); Kattha is a land unit; 30 kattha = 1 hectare. 


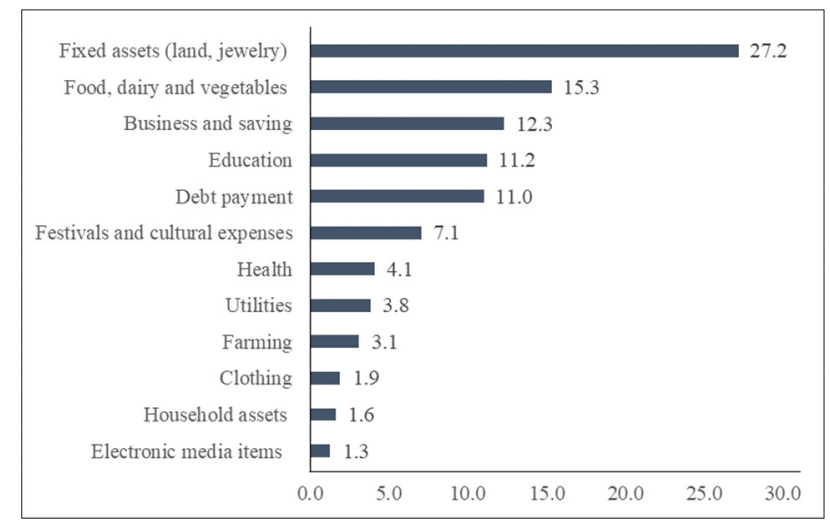

Figure 1. Uses of remittances in various household activities (percent).

With regard to controls, none of the other household level correlates were significantly associated with the use of remittances in farming, except for caste/ethnicity. The households that belonged to Hill Janajati used significantly less amount of remittances in farming as compared to Brahmin/Chhetri households.

Uses of Remittances in Business, Savings and Investment. The results show that the amount of remittances received by households was positively associated with the amount of remittances used in business, saving and investment. However, the result was not statistically significant (0.39; $\mathrm{p}>.05$ ), net of all other controls (Table 2 ).

Uses in Health and Education. The results further show that the amount of remittances received was not positively associated with the amount of remittances used in health $(0.85 ; \mathrm{p}>.05)$ and education $(0.34$; $\mathrm{p}>.05$ ), net of all other controls. These results clearly show that the amount of remittances received by households in Chitwan is not being used in productive investments such as farming, savings, and health and education of family members.

Fixed Assets (Land, Property, and Jewelry). Adjusting for all other factors, the amount of remittances received by a household was positively associated with the amount of remittances used in buying fixed assets such as land and jewelry $(0.80 ; \mathrm{p}<.05)$. One-point increase in a household's receipt of remittances increased the amount of its use to buy land, property and jewelry by 0.80 points, net of all other factors. Some other correlates were also statistically significant. For example, an increase in the age of household members significantly reduced the amount of remittances used in buying fixed assets. Moreover, those households that reported their livelihood options as (a) farming, business and migration, and (b) farming and migration were significantly less likely to use remittances to purchase fixed assets as compared to those who reported that their livelihood option was business and migration. Similarly, as expected, income status of the household was also positively associated with the use of remittances in fixed assets. Households that reported income over NRs 500,001 invested 2.99 times higher amount of remittances in buying fixed assets as compared to those households that reported that their income was below NRs 100,000. Households in stratum 2 and stratum 3 were also more likely to invest in buying assets as compared to those that were living in stratum 1 .

Household Assets. Household items purchased by households included bicycle, motorcycle, refrigerator, rice cooker, gas stove, water pump, electric fans, and furniture. Some households reported remittances being used to purchase these items. The adjusted results in Table 2 show that the purchase of household items marginally increased with the increase in the amount of remittances received, but the association was not significant ( $0.48 ; \mathrm{p}>.05)$, net of all other controls. Moreover, the households that belonged to Terai Janajati were significantly less likely to use remittances to purchase household items as compared to Brahmin/Chhetri (2.59; $\mathrm{p}<.05$ ). Other measures were not significantly associated with the use of remittances.

Electronic Media Items. Various media items (or electronic items) purchased by households included a radio/tape recorder, a TV/DVD/VCR, a cell phone/telephone, and a computer. The adjusted results (Table 3 ) show that the amount of remittances received by households was significantly and positively associated with the amount of remittances used to buy media items $(0.79 ; \mathrm{p}<.05)$. Other correlates that were significantly associated with the amount of remittances used in buying media items were mean age of household members and education. The mean age of household members was significantly but negatively associated with the purchase of household items, suggesting that the households with older members do not spend remittances in buying media items. On the other hand, the average amount of education in the household positively influenced the purchase of household items, which is as expected. Other factors were not significantly associated with the use of remittances in buying such items.

Food Items. The households spent the second largest amount of remittances to purchase food items that included cereals, pulse, vegetables, meat, milk and milk products, oil/spices, and condiments. Households reported that they purchased condiments (sugar, tea, coffee, horlicks) (97.1\% households), oil/spices (95), meat (91.4) and vegetables (87.1). Of the total households, slightly over half the households reported that they used remittances to purchase condiments (sugar, tea, coffee, horlicks) (54.7) and oil/spices (51.8). Other households reported that they purchased meat (45.3\%) followed by vegetables $(41.7 \%)$, oil/spices (25.9\%), and food (cereals) $(21.6 \%)$ (please refer to Bhandari \& Chaudhary, 2017 for detail). The adjusted results from multivariate analysis (Table 2) show that the amount of remittances received by a household was positively associated with the amount of remittances used in buying food items. However, the coefficient was not statistically significant, adjusting for all other factors. This suggests that the amount of remittances received by a household does not influence its use in buying food items. Regarding other factors, the households that reported farming, business, and migration as the livelihood option spent significantly less amount of remittances in buying food items as compared to those whose livelihood option was based on business and migration. On the other hand, Hill Janajati households spent significantly less amount of remittances to purchase food items as compared to Brahmin/Chhetri households. Other factors were not significantly associated with the amount of remittances used in buying food items.

Clothing. The adjusted results show that the total amount of remittances received by a household was positively associated with the amount of remittances used in buying clothes $(0.82 ; \mathrm{p}<.05)$. This suggests that households spent remittances to buy clothes if they receive an increasing amount of remittances from migrants. In addition, Terai Janajati were significantly less likely $(-2.76 ; \mathrm{p}<.05)$ to use remittances to purchase clothes as compared to Brahmin/Chhetri but other caste/ethnic groups were significantly not different from Brahmin/Chhetri. Other factors, however, were not significantly associated with the amount of remittances used in buying clothes. 
Table 2. Multilevel models estimating the amount of remittances (log Nepalese Rupees) used by households in various activities in Chitwan valley of Nepal, 2013 ( $\mathrm{n}=139$ ).

\begin{tabular}{|c|c|c|c|c|c|c|c|c|c|c|c|c|}
\hline Measures & Farming* & $\begin{array}{l}\text { Business, savings } \\
\text { and investment }\end{array}$ & Health & Education & $\begin{array}{l}\text { Fixed assets } \\
\text { (land, jewelry) }\end{array}$ & $\begin{array}{l}\text { Household } \\
\text { assets } \\
\end{array}$ & Media items & Food & Clothes & Culture & Utilities & Debt payment \\
\hline Total remittances received (log NRs) & $-0.04(-0.11)$ & $0.39(0.11)$ & $0.85(0.03)$ & $0.34(0.87)$ & $0.80 *(2.15)$ & $0.48(1.41)$ & $0.79 *(2.52)$ & $0.82(1.99)$ & $0.82 *(2.19)$ & $0.69+(1.76)$ & $0.93 *(2.42)$ & $1.05^{*}(2.38)$ \\
\hline Household members & $-0.23(-0.82)$ & $0.06(0.19)$ & $-0.11 *(-0.36)$ & $-0.38(-1.23)$ & $-0.35(-1.18)$ & $-0.35(-1.26)$ & $-0.31(-1.24)$ & $-0.19(-0.57)$ & $-0.08(-0.30)$ & $-0.25(-0.79)$ & $-0.17(-0.55)$ & $0.09(0.24)$ \\
\hline Mean age of individuals in the household & $0.05(0.76)$ & $0.02(0.31)$ & $0.07(0.93)$ & $-0.11(-1.54)$ & $-0.17^{*}(-2.43)$ & $-0.07(-1.08)$ & $-0.14 *(-2.37)$ & $-0.06(-0.75)$ & $0.001(0.01)$ & $-0.009(-0.13)$ & $-0.10(-1.45)$ & $0.09(1.06)$ \\
\hline Mean age of elderly people in the household & $-0.007(0.18)$ & $-0.04(-1.02)$ & $0.04(0.93)$ & $0.02(0.50)$ & $0.05(1.40)$ & $0.03(0.96)$ & $0.07 *(2.16)$ & $-0.06(-1.39)$ & $-0.03(-0.86)$ & $-0.02(-0.40)$ & $-0.005(-0.12)$ & $-0.11 *(-2.42)$ \\
\hline Mean education of household members & $-0.12(-0.88)$ & $0.15(0.98)$ & $-0.20(-1.38)$ & $-0.27+(-1.85)$ & $0.30(2.13)$ & $0.02(0.18)$ & $0.09(0.83)$ & $-0.03(-0.21)$ & $-0.18(-1.29)$ & $-0.006(-0.04)$ & $-0.12(0.86)$ & $-0.31+(-1.83)$ \\
\hline Livelihoods: Business and migration (Ref) & - & - & - & - & - & - & - & - & - & - & - & - \\
\hline Farming, business and migration & $-2.18(-1.58)$ & $-1.40(-0.96)$ & $-2.28(-1.60)$ & $-0.92(-0.66)$ & $-2.76 *(-2.06)$ & $0.26(0.21)$ & $1.04(0.91)$ & $-4.40 * *(-2.98)$ & $-2.19(-1.61)$ & $-1.19(-0.85)$ & $-2.18(-1.58)$ & $1.07(0.67)$ \\
\hline Farming and migration & $0.33(0.29)$ & $-1.46(-1.22)$ & $-0.62(-0.53)$ & $2.06(1.80)$ & $-2.75 *(-2.5)$ & $0.79(0.78)$ & $0.94(1.00)$ & $-0.68(-0.56)$ & $\begin{array}{l}-1.94+(- \\
1.73)\end{array}$ & $-0.45(-0.39)$ & $0.33(0.29)$ & $0.23(0.18)$ \\
\hline Total cultivated land (kattha) & $0.04(0.33)$ & $-0.08(-0.59)$ & $0.03(0.24)$ & $0.15(1.16)$ & $0.05(0.44)$ & $-0.10(-0.87)$ & $-0.13(-1.31)$ & $0.14(1.07)$ & $0.15(1.26)$ & $0.10(0.81)$ & $0.04(0.33)$ & $0.19(1.30)$ \\
\hline Land squared & $-0.001(-0.32)$ & $0.003(0.95)$ & $-0.0003(-0.10)$ & $-0.004(-1.18)$ & $-0.001(-0.25)$ & $0.004(1.34)$ & $0.004(1.49)$ & $-0.004(-1.41)$ & $-0.004(-1.40)$ & $-0.002(-0.54)$ & $-0.001(-0.32)$ & $-0.005(-1.45)$ \\
\hline \multicolumn{13}{|l|}{ Household income (Nepali Rupees) } \\
\hline Below 100,000 (Ref) & - & - & - & - & - & - & - & - & - & - & - & - \\
\hline $100,001-250,000$ & $-1.51(-1.53)$ & $0.09(0.09)$ & $0.09(0.09)$ & $0.45(0.45)$ & $0.13(0.14)$ & $1.64+(1.88)$ & $0.14(0.18)$ & $-0.91(-0.87)$ & $1.49(1.40)$ & $0.91(0.92)$ & $-1.51(-1.53)$ & $0.24(0.23)$ \\
\hline $250,001-500,000$ & $-1.06(-0.87)$ & $2.25+(1.75)$ & $-0.04(-0.03)$ & $0.24(0.19)$ & $1.41(1.19)$ & $0.11(0.10)$ & $-0.89(-0.88)$ & $-1.43(-1.10)$ & $0.64(0.53)$ & $0.75(0.61)$ & $-1.06(-0.87)$ & $-1.84(-1.30)$ \\
\hline 500,001 and over & $-1.71(-1.36)$ & $1.03(0.78)$ & $-0.05(-0.04)$ & $2.90 *(2.27)$ & $2.99 *(2.45)$ & $0.79(0.71)$ & $-0.74(-0.71)$ & $-1.37(-1.03)$ & $2.02(1.63)$ & $0.93(0.73)$ & $-1.71(-1.36)$ & $-0.23(-0.15)$ \\
\hline Caste/ethnicity: Brahmin/Chhetri (Ref) & - & - & - & - & - & - & - & - & - & - & - & - \\
\hline Dalit & $-1.67(-1.31)$ & $-0.25(-0.19)$ & $-1.47(-1.17)$ & $-0.56(-0.46)$ & $-0.77(-0.65)$ & $0.004(0.00)$ & $1.54(1.53)$ & $-2.55+(-1.88)$ & $-0.38(-0.32)$ & $0.65(0.50)$ & $-1.67(-1.31)$ & $-0.54(-0.39)$ \\
\hline Hill Janajati & $-2.42 *(-2.04)$ & $0.03(0.02)$ & $-2.39 *(-2.03)$ & $-1.62 *(-1.39)$ & $-1.23(-1.11)$ & $1.06(0.99)$ & $0.03(0.03)$ & $-3.42 * *(-2.71)$ & $-1.58(-1.40)$ & $-1.77(-1.48)$ & $-2.42 *(-2.04)$ & $-1.15(-0.87)$ \\
\hline Newar & $0.16(0.10)$ & $-1.08(-0.67)$ & $-1.47(-0.93)$ & $0.15(0.10)$ & $-1.56(-1.04)$ & $-1.59(-1.08)$ & $0.68(0.53)$ & $1.38(0.80)$ & $1.47(0.97)$ & $0.77(0.47)$ & $0.16(0.10)$ & $-1.24(-0.69)$ \\
\hline Terai Janajati & $-1.29(-0.92)$ & $0.74(0.53)$ & $-2.49+(-1.85)$ & $-2.12(-1.60)$ & $0.16(0.13)$ & $-2.59 *(-2.03)$ & $-0.46(-0.42)$ & $-2.04(-1.38)$ & $-2.76 *(-2.14)$ & $-1.86(-1.31)$ & $-1.29(-0.92)$ & $-1.77(-1.16)$ \\
\hline \multicolumn{13}{|l|}{ Household location from Narayanghat } \\
\hline Strata 1 (close) (Ref) & - & - & - & - & - & - & - & - & - & - & - & - \\
\hline Strata 2 (middle) & $-1.66(-1.50)$ & $0.90(0.87)$ & $-0.25(-0.25)$ & $-0.81(-0.83)$ & $3.14^{* * *(3.32)}$ & $-0.18(-0.17)$ & $-1.23(-1.53)$ & $-0.10(-0.09)$ & $-0.67(-0.70)$ & $-2.25(-1.99)$ & $-1.66(-1.50)$ & $1.09(0.97)$ \\
\hline Strata 3 (far) & $-0.62(-0.51)$ & $0.74(0.66)$ & $1.03(0.93)$ & $-0.99(-0.92)$ & $2.00+(1.92)$ & $0.22(0.20)$ & $-0.68(-0.76)$ & $0.82(0.64)$ & $0.10(0.09)$ & $0.04(0.03)$ & $-0.62(-0.51)$ & $0.62(0.50)$ \\
\hline Intercept & -0.22 & -2.04 & -5.2 & 7.83 & -6.21 & -2.31 & -6.03 & 5.64 & -1.02 & 1.1 & -0.22 & -4.22 \\
\hline$-2 \log L$ (deviance) & 793.6 & 806.3 & 800.1 & 795.8 & 795.9 & 765.7 & 747.2 & 809.8 & 789.5 & 796.7 & 793.6 & 829.3 \\
\hline AIC & 797.6 & 808.3 & 802.1 & 797.8 & 787.9 & 769.7 & 749.2 & 813.8 & 791.5 & 800.7 & 797.6 & 831.3 \\
\hline $\mathrm{BIC}$ & 800.3 & 809.7 & 803.4 & 799.2 & 789.9 & 772.5 & 750.6 & 816.5 & 792.8 & 803.4 & 800.3 & 832.7 \\
\hline
\end{tabular}

US\$ $1=100$ Nepali Rupees (2013). Figures in parenthesis are t-statistics. $+\mathrm{p}<.10,{ }^{*} \mathrm{p}<.05,{ }^{* *} \mathrm{p}<.01,{ }^{* * *} \mathrm{p}<.001$. 
Festivals and Cultural Expenses. Slightly over 22 percent of the households reported that they used remittances in weddings, and a small fraction of them used remittances in pilgrimage (5.8), funerals (7.2\%), and birth related rituals (birthday, paasni, bratabandha) (6.5). The adjusted results show that the amount of remittances received by a household was weakly but positively associated with the amount of remittances used ( 0.69 ; $\mathrm{p}<.10)$. None of the other controls were significantly associated with the amount of remittances used in cultural events.

Utilities. The results show that the amount of remittances received by a household was positively and significantly associated with the amount of remittances used in paying utilities $(0.93 ; \mathrm{p}<.05)$. This result suggests that an increase in the amount of remittances received by a household increases the amount spent in paying utilities. None of the other controls except caste/ethnicity had a significant association with the amount of remittances used in utilities. The Hill Janajati households spent significantly less amount of remittances in utilities as compared to Brahmin/Chhetri households.

Debt Payment. The multivariate results show that the amount of remittances received by a household was positively associated with the amount of remittances used in paying debt $(1.05 ; \mathrm{p}<.05)$. Among other factors, only the mean age of elderly people in the household significantly reduced the use of remittances in debt payment. Other factors were not significantly associated with the amount of remittances used in debt payment.

\section{Conclusion}

Outmigration of much of the young labor force from rural agriculture has been a common phenomenon in most developing countries. In fact, outmigration of youths, particularly men, has been a 'rite-of-passage' in countries such as Nepal. While rural agriculture is expected to decline due to significant labor loss, on the contrary, there is an expectation that the remittance from outmigration would be utilized in farming, which would compensate for labor loss and agriculture would flourish. Farm households are generally expected to utilize remittances for land improvement and invest in labor-saving but production-enhancing technologies such as the use of machines, improved seeds, and other production augmenting inputs. However, there is a dearth of empirical evidence of the uses of remittances in farming and other dimensions of household activities. This study evolves from a growing concern about productive vs. consumptive uses of remittances in a rural migrant-sending setting of Nepal, one of the highly suitable areas for farming that is experiencing massive outmigration of young individuals. Specifically, this paper investigated the extent to which the amount of remittances received by a household is being used in farming as compared to other dimensions of household activities.

Using the household level data collected from the western Chitwan Valley of Nepal, the results showed that only a small fraction of remittances that is received by households from migrants is spent in farming by remittance-receiving households in this agrarian setting. Of the total amount of remittances spent in various dimensions of activities, farming (e.g. purchase of seeds, fertilizers, and pesticides) received only 3.1 percent of the total remittances spent. A large proportion of remittances was used in buying fixed assets such as land, house, and jewelry which is followed by food (cereals) and vegetables, savings and business investment, loan payment, education, and health. Adjusted results further suggested that the total amount of remittances received by a household was not significantly associated with the amount of remittances invested in farming. Despite the fact that most migrants are from rural farming households, investment of remittances in farming is minimal. This result is surprising and rather frustrating to those who are advocating for the role of remittances in agricultural development in developing countries. On the contrary, households used increasing amounts of remittances in clothing, buying fixed assets and media items, paying for utilities and debt, and celebrating various cultural festivals. Households' allocation of received remittances was not significantly associated with productive investments such as in farming, savings and investments, healthcare, and education of the household members.

Based on the findings, it is concluded that rural agriculture in Nepal is facing a double loss - the loss of working labor force and the lack of investment of remittances in farming. Rather the remittance is being used in items such as buying land and property, food, clothes, for cultural events and so on. This scenario will be detrimental to agricultural production and productivity in the country where a large amount of food items is imported daily. The lack of investment of remittance income in farming will further encourage more food imports in the days to come. Therefore, it is an urgent need for researchers and policymakers to begin designing appropriate policies to encourage farm households and migrant youths to allocate a certain portion of remittances for agricultural development.

This study has several contributions. This study offers empirical evidence of the uses of remittances in farming as well as in other productive and consumptive activities by remittance-receiving households. This has helped us generate questions for future studies such as why the remittancereceiving households are not interested in investing remittance income in farming. We also need to understand what strategies should be adopted by the government so that the receiving households could invest some portion of remittance income in farming and other productive activities. It is believed that the findings will be useful in developing frameworks and testing the causality of the effects of productive vs. consumptive expenditures of remittances on the socio-economic well-being of remittance-receiving households. These findings will be of interest to those studying the long-term consequences of migration and remittances in sustaining/reducing household level poverty. The findings are based on data from a small sample of a small part of the southern Terai of Nepal; therefore, the results of this study may not be generalized to other areas. Moreover, the data is cross-sectional in nature. Thus, the conclusions should be considered rather cautiously, and additional studies from other regions of the country are needed to come to a firm conclusion.

\section{Acknowledgements}

This research was supported by the Ronald Freedman and Marshall Weinberg Fund through the Population Studies Center's Small Grant for Measurement of Remittance Use in a Remittance Dependent Economy at the University of Michigan. I thank Ms. Indra Chaudhary and Dr. Dirgha Ghimire for their support. I also thank the field research staff of the Institute for Social and Environmental Research-Nepal (ISER-N) for their contributions in data collection and Mr. Bishnu Adhikari, Data Manager, ISER-N for assisting with data quality checking and data management. I 
owe a special debt of gratitude to our survey respondents who continuously welcome us to their homes and share their invaluable experiences, opinions, and thoughts and who have devoted countless hours responding to our survey questionnaires.

\section{References}

Adams, R. H., Jr. (1998). Remittances, investment, and rural asset accumulation in Pakistan. Economic Development and Cultural Change, 47(1), 155-173.

Adams, R. H., Jr. (2011). Evaluating the economic impact of international remittances on developing countries using household surveys: A literature review. The Journal of Development Studies, 47(6), 809-828.

Barber, J. S., Shivakoti, G. P., Axinn, W. G., \& Gajurel, K. (1997). Sampling strategies for rural settings: A detailed example from the Chitwan Valley Family Study, Nepal. Nepal Population Journal, 6(5), 193-203.

Beijer, G. (1970). International and national migratory movements. International Migration, 8(3), 93-109.

Bhandari, P. (2016). Remittance received by households of western Chitwan Valley, Nepal: Does migrant's destination make a difference? Dhaulagiri Journal of Sociology and Anthropology, 10, 1-36.

Bhandari, P., \& Chaudhary, I. (2017). A calendar method of collecting remittance use data in a remittance dependent setting of Nepal. Migration and Development, 6(2), 177-197.

Bhandari, P., \& Ghimire, D. (2013). Rural agricultural change and fertility transition in Nepal. Rural Sociology, 78(2), 229-252.

Brown, R. P. C., \& Ahlburg, D. A. (1999). Remittances in the South Pacific. International Journal of Social Economics, 26, 325-344.

Central Bureau of Statistics (2012). Population Census 2011 - Preliminary Report. Government of Nepal. Kathmandu.

De Brauw, A. (2007). Seasonal migration and agriculture in Vietnam (No. 0704). Retrieved from Agricultural and Development Economics Division of the Food and Agriculture Organization of the United Nations (FAO - ESA) website: https://ideas.repec.org/p/fao/wpaper/0704.html.

De Brauw, A., Taylor, J. E., \& Rozelle, S. (1999). The impact of migration and remittances on rural incomes in China. Proceedings, 1999 American Agricultural Economics Association Annual Meetings, Nashville, August 8$11,1999$.

De Haas, H. (2007). Remittances, migration and social development. A conceptual review of the literature. Social Policy and Development Programme Paper Number 34. United Nations Research Institute for Social Development, Switzerland.

Ecer, S., \& Tompkins, A. (2013). An econometric analysis of the remittance determinants among Ghanaians and Nigerians in The United States, United Kingdom, and Germany. International Migration, 51, e53-e69.

Eversole, R., \& Johnson, M. (2014). Migrant remittances and household development: An anthropological analysis. Development Studies Research. An Open Access Journal, 1(1), 1-15.

Government of Nepal 2071 (2014). National Population Policy 2071. Government of Nepal. Ministry of Health and Population, Kathmandu, Nepal.

Gurung, H. B. (1998). Nepal, social demography and expressions. Kathmandu, Nepal: New Era.

Gurung, H. B. (1983). Internal and international migration in Nepal. Kathmandu, Nepal: HMG Population Commission.

Hoermann, B., \& Kollmair, M. (2009). Labour migration and remittances in the Hindu Kush-Himalayan Region. 20. ICIMOD Working Paper. Kathmandu, Nepal.

IOM. (2017, October 24). World migration report 2018. Retrieved July 26, 2019, from International Organization for Migration website: https://www.iom.int/wmr/world-migration-report-2018
Jokisch, B. D. (2002). Migration and agricultural change: The case of smallholder agriculture in highland Ecuador. Human Ecology, 30(4), 523550 .

Kandel, W., \& Massey, D. S. (2002). The culture of Mexican migration: A theoretical and empirical analysis. Social Forces, 80(3), 981-1004.

Kern, A., \& Müller-Böker, U. (2015). The middle space of migration: A case study on brokerage and recruitment agencies in Nepal. Geoforum, 65, 158169.

Kindleberger, C. P. (1967). Europe's postwar growth: The role of labor supply. Harvard University Press.

Koc, I., \& Onan, I. (2006). International migrants' remittances and welfare status of the left-behind families in Turkey. International Migration Review, 38(1), 78-112.

Kollmair, M., Manandhar, S., Subedi, B., \& Thieme, S. (2006). New figures for old stories: Migration and remittances in Nepal. Migration Letters, 3(2), 151-160.

Massey, D. S., \& Bassem, L. C. (1992). Determinants of savings, remittances, and spending patterns among U.S. migrants in four Mexican Communities. Sociological Inquiry, 62(2), 185-207.

Nepal Living Standard Survey. (2011). Nepal living standard survey 2010/11Statistical report. Kathmandu: Central Bureau of Statistics, Government of Nepal.

Nepal Rastra Bank. (2016). Fifth household budget survey 2014/14. Nepal Rastra Bank. Kathmandu, Nepal.

Oberai, A. S., \& Singh, H.K.M. (1980). Migration, remittances and rural development: Findings of a case study of the rural Punjab. International Labour Review, 119(2), 229-241.

Pant, B. (2008). Mobilizing remittances for productive use: A policy-oriented approach. Nepal Rastra Bank, Research Department Working Paper, 4.

Pariyar, M. P., Shrestha, K. B., \& Dhakal, N. H. (2001). Baseline study on agricultural mechanization needs in Nepal. CIMMYT.

Pattison, P. (2014). For aspiring Nepali migrants, the risks start at home. $\begin{array}{llll}\text { Retrieved July 26, 2019, from } & \text { 26 }\end{array}$ http://america.aljazeera.com/articles/2014/12/15/for-aspiringnepalimigrantstherisksstartathome.html

Rathaur, K. R. S. (2001). British Gurkha recruitment: A historical perspective. Voice of History, 16(2), 19-24.

Reichert, J. (1981). The migrant syndrome: Seasonal U.S. wage labor and rural development in Central Mexico. Human Organization, 40(1), 56-66.

Rempel, H., \& Lobdell, R. A. (2007). Determinants of savings, remittances, and spending patterns among U.S. migrants in four Mexican Communities. Sociological Inquiry, 62(2), 185-207.

Seddon, D. (2004). South Asian remittances: Implications for development. Contemporary South Asia, 13(4), 403-420.

Seddon, D., Adhikari, J., \& Gurung, G. (2002). Foreign labor migration and the remittance economy of Nepal. Critical Asian Studies, 34(1), 19-40.

Sharma, J., \& Gurung, G. (2009). Impact of global economic slowdown on remittance inflows and poverty reduction in Nepal. Institute for Integrated Development Studies. Kathmandu.

Shivakoti, G. P., Axinn, W. G., Bhandari, P., \& Chhetri, N. B. (1999). The impact of community context on land use in an agricultural society. Population and Environment, 20(3), 191-213.

Shrestha, N. R. (1990). Landlessness and migration in Nepal. Boulder, San Francisco. Oxford: Westview Press.

Stark, O., \& Bloom, D. E. (1985). The new economics of labor migration. The American Economic Review, 75(2), 173-178.

Taylor, E. J. (1999). The new economics of labour migration and the role of remittances in the migration process. International Migration, 37(1), 63-88.

Taylor, J. E., \& Martin, P. L. (2001). Human capital: Migration and rural population change. Handbook of Agricultural Economics, 1, 457-511.

Taylor, J. E., \& Yúnes-Naude, A. (1999). Education, migration and productivity: An analytic approach and evidence from rural Mexico. 
Organization for Economic Co-operation and Development. Retrieved from https://doi.org/10.1787/9789264172852-en

Thieme, S., \& Wyss, S. (2005). Migration patterns and remittance transfer in Nepal: A case study of Sainik Basti in western Nepal. International Migration, 43(5), 59-98.

World Migration Report 2010. (2015, January 30). Retrieved July 29, 2019, from International Organization for Migration website: https://www.iom.int/world-migration-report-2010.
World Bank. (2009). Impact of global financial crisis on South Asia. Washington: World Bank.

World Bank. (2011). Migration and development brief 17. Migration and Remittances Unit, Washington, DC: The World Bank.

World Bank. (2016). Migration and remittances factbook 2016. Third Edition. World Bank Group, Washington, DC: The World Bank. https://siteresources.worldbank.org/INTPROSPECTS/Resources/3349341199807908806/4549025-1450455807487/Factbookpart1.pdf. 